\title{
Female reproductive patterns in hibernating bats
}

\author{
B. A. Oxberry \\ Department of Anatomy, College of Medicine, University of Arizona, Tucson, Arizona 85724, \\ U.S.A.
}

\begin{abstract}
Summary. Hibernation exerts a profound influence on the physiology of reproduction in two families of bats, Vespertilionidae and Rhinolophidae. The imposition of a period of hibernation on the female reproductive cycle appears to arrest the progress of reproductive events begun in the autumn and to postpone their completion until spring. The sequence of reproductive events in hibernating bats follows one of two basic patterns. In the Type I pattern, oestrus and copulations are initiated in late summer and early autumn and the bats typically enter hibernation soon thereafter. Intermittent arousal and additional copulations may occur throughout the hibernation period. Spermatozoa are then stored in the female reproductive tract until after permanent arousal in the spring when ovulation, fertilization and gestation take place. In the Type II pattern, copulation in autumn is followed immediately by ovulation, fertilization and initial embryogenesis, and females enter hibernation in a pregnant condition. During hibernation, implantation is delayed and does not occur until after permanent arousal in the spring. The significant features that are of special interest in the reproductive processes of hibernating bats are the delay of ovulation and storage of sperm following autumn copulation in Type I or, alternatively, the delay of implantation following autumn fertilization in Type II. Morphological, physiological and experimental analyses of gamete and steroid production by the ovary and of pituitary control of these processes with respect to hibernation are reviewed in this paper. The evidence indicates that hibernation and the external factors regulating it act to suppress endocrine activity of the pituitary and ovary, resulting in the protraction of certain stages of the reproductive cycle. Although this argument is especially persuasive with respect to ovarian function, a comprehensive understanding of the mechanisms controlling the progress of reproductive events and their delay in these bats is lacking. Accordingly, areas that require elucidation are discussed.
\end{abstract}

\section{Introduction}

The ability to undergo facultative torpor and hibernation has been well documented in two families of bats, Vespertilionidae and Rhinolophidae (Brosset, 1961; Kulzer, 1965; McNab, 1969; Henshaw, 1970; Lyman, 1970; Studier \& O'Farrell, 1972) and probably is present to some degree in a few others, such as Rhinopomatidae, Mystacinidae and Molossidae. This paper considers only the first two families, in which hibernation has been shown to exert a profound influence on the physiology of reproduction.

Hibernation is a deep, prolonged torpor with only short periodic arousals, and it is characteristically associated with the stress of low ambient temperatures and/or restricted food supplies. Torpor and hibernation are physiologically purposeful acts, in which the animal lowers its metabolic rate and regulates its body temperature at a level slightly above the ambient temperature. Furthermore, the animal is capable of spontaneous self-arousal, or arousal can be induced by external physical factors (Lyman, 1970). The adaptive significance of hibernation is energy conservation; it therefore can be expected to influence, or be influenced by, another energetically expensive function, reproduction. Such mutual effects are particularly apparent 
when a period of hibernation is superimposed on the reproductive cycle: hibernation appears to arrest the progress of reproductive events begun in the autumn and to postpone their completion until after the animals emerge from hibernation in the spring. These phenomena in bats have been previously reviewed by several authors (Wimsatt, 1960, 1969; Asdell, 1964; Carter, 1970). I shall reconsider much of the same work in the light of more recent contributions and attempt to put them in perspective with present day concepts of reproductive physiology. In addition, I shall discuss areas where further studies are necessary for a better understanding of the operation of mechanisms controlling reproductive events in hibernating bats.

\section{Hibernation and female reproduction in bats}

\section{Reproductive patterns}

The timing of reproductive events in hibernating bats follows one of two basic patterns. In Type I (Text-fig. 1a), a brief pro-oestrus occurs in late summer. Oestrus and subsequent copulations are initiated in late summer and early autumn, and the bats typically enter hibernation soon thereafter. Intermittent arousal and additional copulations may occur throughout the hibernation period. Spermatozoa are stored in the female reproductive tract until after permanent arousal in the spring, when ovulation, fertilization and gestation take place. Parturition occurs in late spring or early summer, followed by a lactational anoestrous period. This general pattern has been well documented in many North American vespertilionid bats (Guthrie, 1933; Guthrie \& Jeffers, 1938a, b; Reeder, 1939; Wimsatt, 1944a, 1945; Guthrie, Jeffers \& Smith, 1951; Pearson, Koford \& Pearson, 1952; Orr, 1954; Christian, 1956; Druecker, 1972; Krutzsch, 1975). Moreover, it is characteristic of the majority of hibernating vespertilionids and rhinolophids in the temperate regions of Europe, Asia and Australia (Courrier, 1924; Nakano, 1928; Caffier \& Kolbow, 1934; Eisentraut, 1936; Matthews, 1937; Sluiter \& Bels, 1951; Sluiter \& Bowman, 1951; Asdell, 1964; Dwyer, 1966; Kleiman, 1969; Kitchener, 1975). However, among the Old World hibernating bats a second basic reproductive pattern (Type II) is found in certain species of the vespertilionid genus Miniopterus and the rhinolophid genus Rhinolophus (Text-fig. 1b). In these bats, a brief pro-oestrus occurs in late summer. Oestrus and copulation occur in the autumn, followed immediately by ovulation, fertilization and initial embryogenesis. The bats then enter hibernation in a pregnant condition with unimplanted blastocysts in their uteri. Upon permanent arousal in the spring, the blastocyst implants and embryonic development is resumed. Parturition occurs in the late spring, followed by a lactational anoestrous period. This Type II pattern has been confirmed for Miniopterus schreibersii in southern Europe (Courrier, 1927; Planel, Guilhem \& Soleilhavoup, 1961; Peyre \& Herlant, 1963a, b; 1967) and in Australia (Dwyer, 1963; Richardson, 1976, 1977), and has been reported to occur in India in a temperate, hibernating population of Rhinolophus rouxi (Ramakrishna \& Rao, 1977). Previously, the Type II pattern was also thought to apply to $M$. australis in temperate regions of Australia (Dwyer, 1968); however, more detailed studies have recently shown that the period of delayed implantation, if it occurs at all, is very brief (Richardson, 1976, 1977). Instead, a third reproductive pattern, incorporating a slowed or prolonged gestation after implantation and attributable to periods of torpor or hibernation, may exist in this species and also in certain other vespertilionids and rhinolophids. This third pattern has not yet been conclusively established; evidence for its existence is discussed later in this paper.

\section{Reproductive specializations}

The imposition of a period of hibernation upon the reproductive cycle seems temporarily to arrest the sequence of reproductive events, either before ovulation or before implantation. To 
(a)

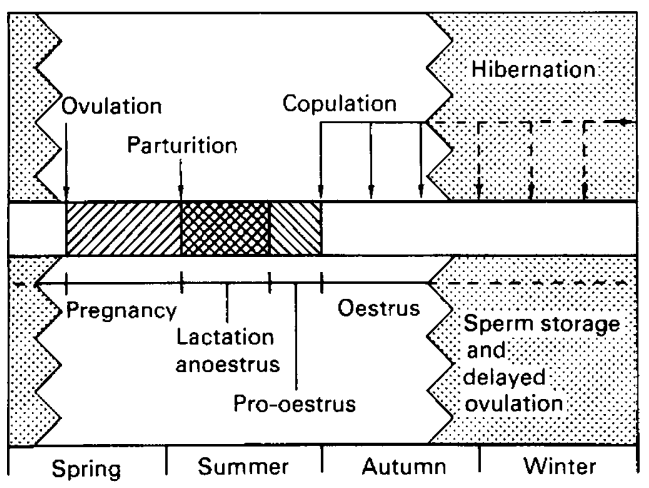

(b)

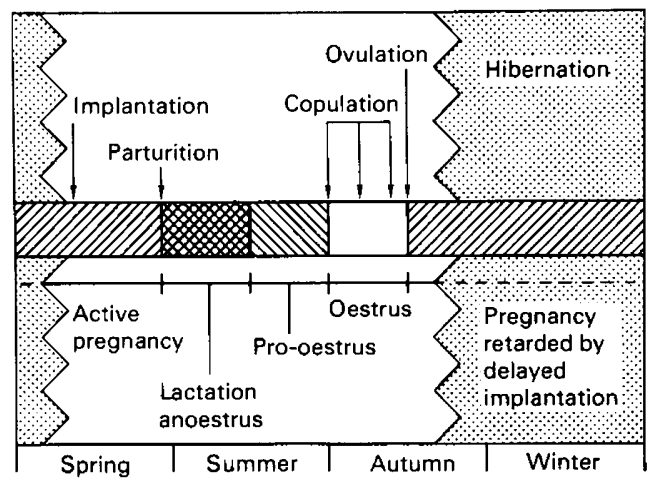

Text-fig. 1. Diagrams to show the (a) Type 1 and (b) Type II reproductive patterns.

cope with these delays, female hibernating bats have adopted a number of unique reproductive specializations.

Follicles of hibernation. In the ovary, the process of growth and differentiation of germ cells and their associated follicular secretory cells, in concert with the process of atresia, culminates in the production of a species-characteristic number of gametes at ovulation. All hibernating bats are monoestrous, and therefore in most of these animals ova are produced once a year.

The ovarian cycle has been examined histologically in various vespertilionid bats that utilize the Type I general reproductive pattern (Guthrie \& Jeffers, 1938a, b; Guthrie, 1939; Wimsatt, 1944a; Guthrie et al., 1951; Sluiter \& Bels, 1951; Pearson et al., 1952; Appley, 1971; Krutzsch, 1975). The results of these studies can be summarized as follows: (1) the processes of growth, differentiation and atresia have been characterized by analysis of follicular age, number and components (cross-sectional areas, volumes and surface areas); (2) normal growth emerges as a synchronized, repetitious occurrence of identical structural features and trends in the follicular components; (3) deviations from the synchronized repeat patterns relate to follicular destruction or atresia and the origin of interstitial cells; (4) several follicular growth waves occur during the single oestrous cycle; and (5) the growth wave just before hibernation produces a species-specific number of specialized vesicular follicles which persist throughout hibernation to rupture in the spring.

The essentials of the follicular cycle in these Type I bats are similar to those reported in other mammals. The unique feature is the persistence of large, mature, Graafian follicles throughout the hibernation period (Pl. 1, Fig. 1). These surviving follicles have been shown to be structurally specialized (Wimsatt, 1942; Wimsatt \& Kallen, 1957; Wimsatt \& Parks, 1966). The ovum is surrounded by a large discus proligerus, the cells of which are markedly hypertrophied and vesiculated in association with the accumulation of massive quantities of glycogen (Pl. 1, Figs 1 and 2). Furthermore, there is evidence that the ovum utilizes this glycogen as an energy source throughout hibernation.

The follicular cycle of hibernating rhinolophids that exhibit the Type I pattern is similar (Matthews, 1937). A difference, however, is that although a large recognizable Graafian follicle persists through the post-copulation period of hibernation, it does not have a large discus proligerus of hypertrophied cells. Presumably, therefore, the follicle does not contain massive amounts of glycogen.

Delayed ovulation. Vespertilionids and rhinolophids with the Type I reproductive pattern postpone the terminal vesiculation and ovulation stages of the follicles of hibernation until spring. Wimsatt (1960) felt that the mechanism for ovulatory delay involved the interplay of at least three factors: the depressing effects of hibernation itself on cellular metabolism and reactivity, a probable dissociation in time of pituitary gonadotrophic function and a neural mechanism that 
may regulate pituitary gonadotrophic function, itself triggered by environmental and/or internal stimuli. Numerous investigators have experimented with these factors in an attempt to deduce the mechanism or mechanisms controlling ovulation in these hibernating bats (Guthrie, 1933; Zondek, 1933; Caffier, 1934; Caffier \& Kolbow, 1934; Guthrie \& Jeffers, 1938c; Guthrie \& Smith, 1940; Sluiter \& Bels, 1951; Smith, 1951; Pearson et al., 1952; Sluiter, Bels \& Van Oordt, 1952; Herlant, 1954; Skreb, 1955; Wimsatt, 1960; Racey, 1976). From this conglomeration of evidence, involving the injection of various pituitary extracts or hormones and steroids into torpid and aroused bats at various times during the hibernation period, a number of principles can be derived: (1) ovulation cannot be induced in torpid bats, only bats aroused from hibernation and kept active can be induced to ovulate; (2) bats aroused from hibernation will spontaneously ovulate, with increasingly greater frequency as the end of their normal period of hibernation approaches; (3) luteinizing hormone (LH), pituitary extracts containing $\mathbf{L H}$, hormones having LH-like activity or impure hormones that could have contained $\mathrm{LH}$ are most effective for inducing ovulation; (4) oestrogen, believed to induce the release of pituitary LH in other mammals, also can induce ovulation in these bats; (5) prolactin may be able to induce ovulation; (6) bats need not have been inseminated to be induced to ovulate with hormones; (7) bats need not have entered hibernation for ovulation to be induced.

As has been established for other mammals, pituitary LH seems to be the specific ovulating hormone in bats. It is also apparent that hibernation depresses cellular metabolism, probably suppressing synthesis and release of pituitary LH and the ability of the ovary to respond. However, even when bats are aroused and kept active, they tend to ovulate spontaneously only toward the end of their normal hibernation period. This information, in conjunction with cytological studies correlating changes in the number and staining intensity of the pituitary cells considered responsible for LH secretion, suggests that there is insufficient pituitary LH present, especially during the first half of hibernation (Herlant, 1956, 1968; Wimsatt, 1960). This deficit may be a consequence of lowered metabolic rate in hibernation and/or of neural regulation of the pituitary triggered by environmental stimuli.

Sperm storage. A review of sperm storage and survival by Racey (1979) is the subject of a separate paper in this symposium, and therefore will not be considered extensively here. Briefly, female hibernating vespertilionid and rhinolophid bats with the Type I pattern have evolved a major specialization which is highly significant for reproductive success when copulation precedes ovulation by an appreciable amount of time: the ability to store viable spermatozoa in their reproductive tracts throughout hibernation (Pl. 1, Figs 3 and 4). In at least some species, it has been demonstrated conclusively that females inseminated by copulation before hibernation are fertilized when they ovulate in the spring (Hartman, 1933; Folk, 1940; Wimsatt, 1942, 1944b; Orr, 1954; Racey, 1973a). However, it has also been argued that for some species additional copulations during the hibernation period and even after arousal in the spring may be necessary to assure fertilization, because the initial spermatozoa may either lose their capacity to fertilize or be expelled from the female reproductive tract (Guthrie, 1933; Hartman, 1933; Guthrie \& Jeffers, 1938b, c; Krutzsch, 1975). The latter may be true in species that frequently arouse from hibernation and resume normal activity for short periods of time.

Silent heat. Among the Old World hibernating bats utilizing Type II reproduction patterns, at least two kinds of follicular cycles seem to occur with respect to their monoestrous breeding. In Europe, Miniopterus schreibersii apparently has a typical mammalian monoestrous follicular cycle in which a single follicular growth wave (in this case the one just prior to hibernation) annually produces a follicle which proceeds to rupture directly. The process is also coincidental with behavioural oestrus, so that concurrent copulations ensure that ovulation will be immediately followed by fertilization (Courrier, 1927). In Australia, $M$. schreibersii likewise has a follicular growth cycle culminating with ovulation and fertilization just before hibernation (Dwyer, 1963; Richardson, 1976, 1977). However, an additional ovulation with apparent absence of behavioural oestrus occurs 2 months earlier, at a time when males do not even have spermatozoa to deliver. 

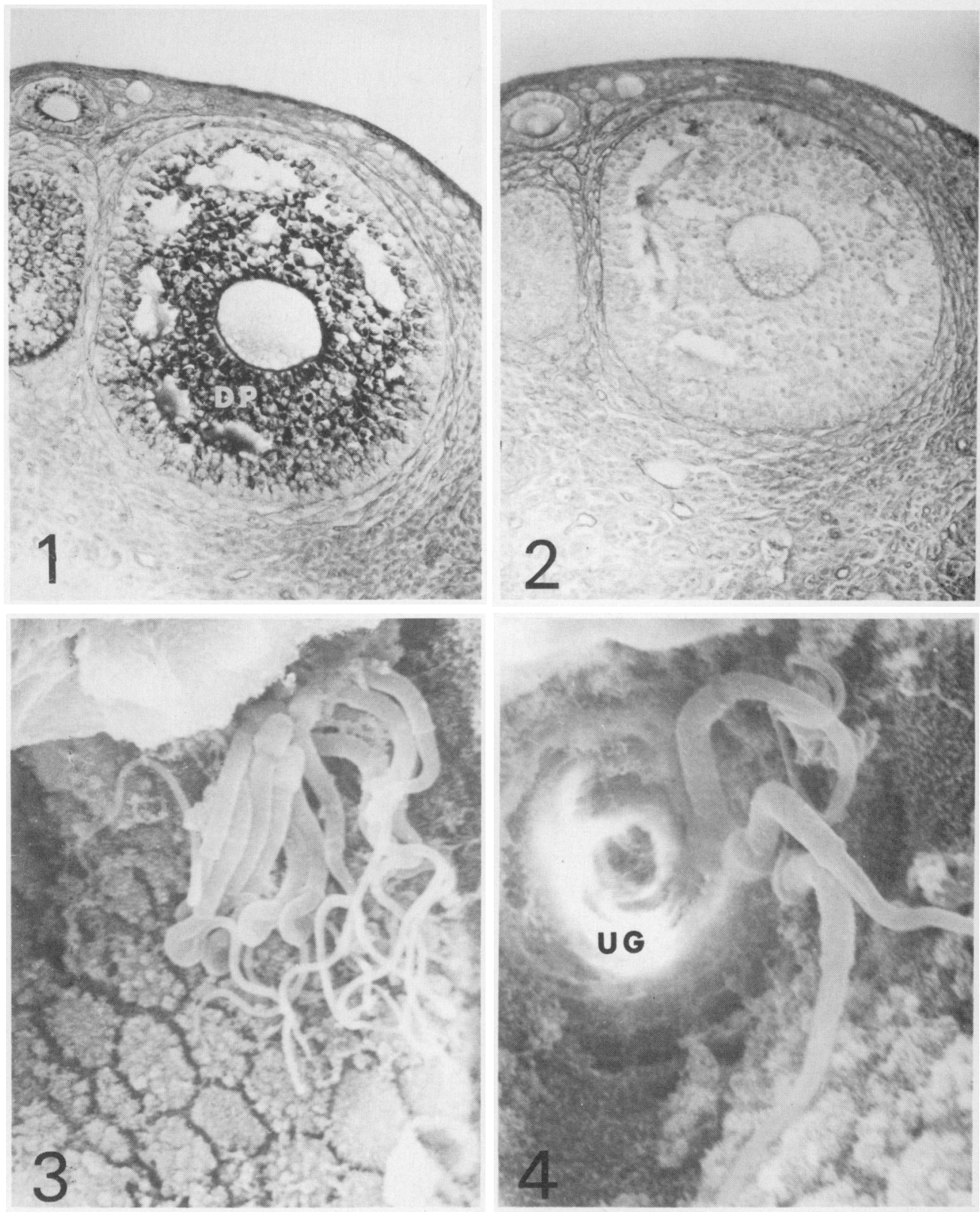

Fig. 1. Follicle of hibernation from a vespertilionid bat (Antrozous pallidus) with the Type I reproductive pattern. Cells of the discus proligerus (DP) are stained intensely for glycogen with periodic acid-Schiff's reagent. $\times 175$.

Fig. 2. Control section adjacent to that in Fig. 1 which was digested with diastase to remove glycogen and then stained with periodic acid-Schiff's reagent. $\times 175$.

Fig. 3. Scanning electron micrograph of spermatozoa stored in the uterus of a bat (Antrozous pallidus) in hibernation. $\times 3000$.

Fig. 4. Scanning electron micrograph of spermatozoa clustered around the orifice of a uterine gland (UG) in a bat (Antrozous pallidus) in hibernation. $\times 10000$. 

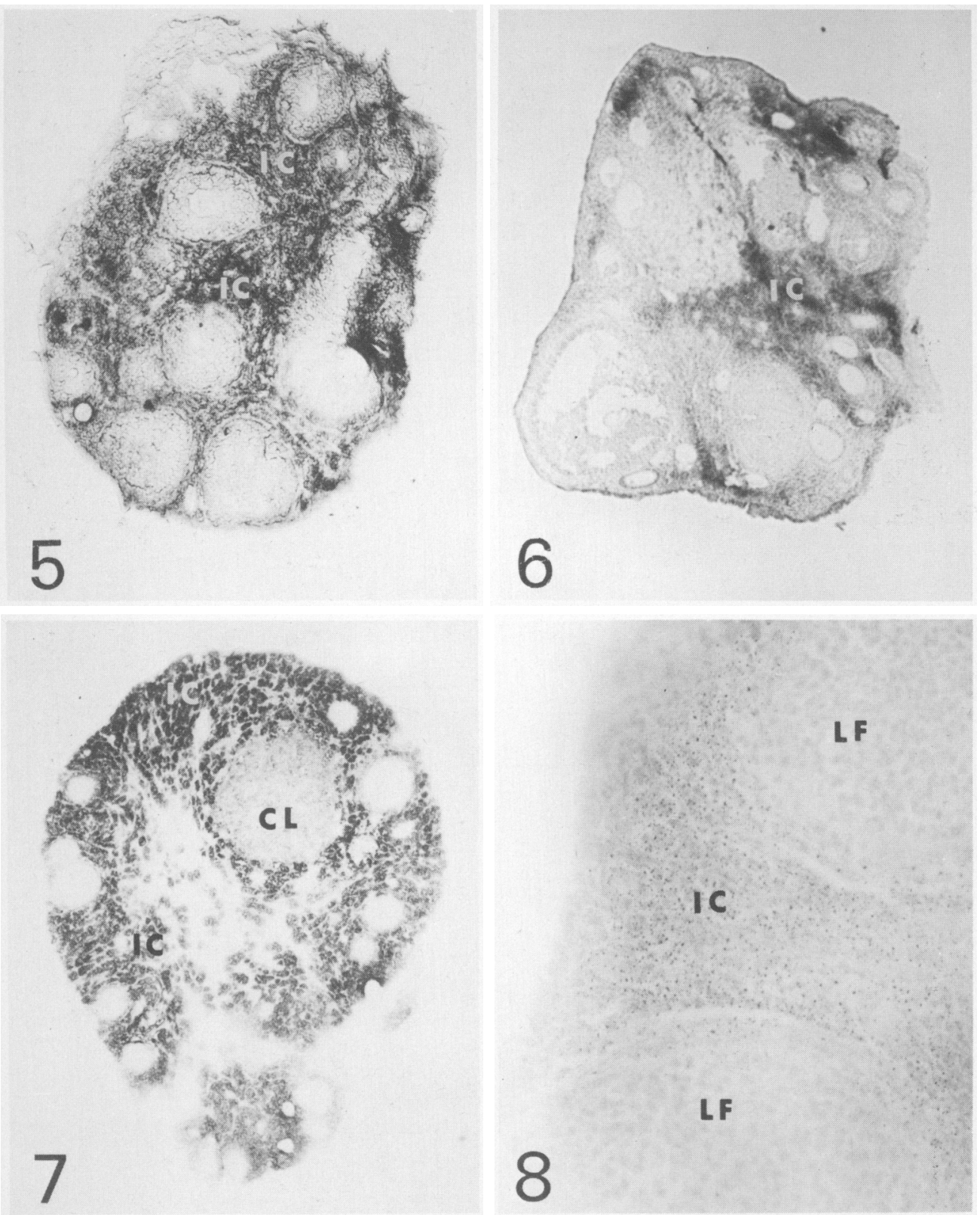

Fig. 5. Ovary of Antrozous pallidus during hibernation. Interstitial cells (IC) are stained intensely for lipids with bromine-Sudan black. $\times 49$.

Fig. 6. Ovary of Antrozous pallidus during oestrus. Interstitial cells (IC) contain dark reaction product after histochemical staining for $3 \beta$-HSD. $\times 49$.

Fig. 7. Ovary of Antrozous pallidus during early pregnancy. Interstitial cells (IC) and corpus luteum $(C L)$ contain dark reaction product from $3 \beta$-HSD histochemistry. $\times 36$.

Fig. 8. Portion of an ovary of Antrozous pallidus during oestrus. Interstitial cells (IC) between two large follicles (LF) contain granulated, dark reaction product from 17 $\beta$-HSD histochemistry. $\times 290$. 
This phenomenon has been termed 'silent heat' (Richardson, 1976, 1977). The existence of a shorter period of hibernation in Australia means that the time between the end of lactation or anoestrus and the beginning of hibernation is long enough to accommodate two consecutive ovulatory cycles, whereas in Europe the shorter time available probably prohibits this occurrence. However, the foregoing are only conditions that allow 'silent heat' to take place; the origin and reason (if any) for its occurrence are not clear.

Delayed implantation. In those hibernating bats utilizing the Type II reproductive pattern the period of delayed implantation coincides almost exactly with the length of winter hibernation. For Miniopterus schreibersii in Europe this time span is 5 months, while in Australia it is 3 months and for a hibernating population of Rhinolophus rouxi in India it is $1 \frac{1}{2}$ months (Planel $e t$ al., 1961; Peyre \& Herlant, 1963a, b, 1967; Richardson, 1976, 1977; Ramakrishna \& Rao, 1977). Wimsatt $(1969,1975)$ theorizes that the delay could be purely a passive response to cold, acting to depress metabolism, or that it could be directed by an active regulatory influence. The latter possibility is supported by the correlation of pituitary cytology with the events of the reproductive cycle. The evidence suggests that an arrest in LH secretion following ovulation, coupled with insufficient prolactin, is responsible for delayed implantation (Peyre \& Herlant, 1963a, b, 1967). While this interpretation implicates participation of the neuroendocrine system in the control of delayed implantation, it also allows for the probability that the action of the system is influenced, at least in part, by the metabolic effects of hibernation or external stimuli.

\section{Ovarian steroidogenesis}

In studies of the ovaries of hibernating bats, attention has been focused on the chronology of various morphological changes and on correlating these with reproductive events occurring elsewhere in the organism in an attempt to deduce the underlying endocrine functions. However, to understand better the endocrine function of the ovary, more specific techniques must be applied to resolve the sites and levels of ovarian steroidogenesis during the reproductive cycle.

Lipids, particularly cholesterol and its esters, are the substrates for the synthesis of the principal sex steroids, oestrogen and progesterone. Therefore, evaluation of lipids and steroidogenic enzymes in the ovaries is a means of assessing steroidogenesis. To a lesser extent such evaluation may reflect changes in levels of the gonadotrophins that are known to regulate these lipids and enzymes. The ovaries of some hibernating vespertilionid bats with the Type I reproductive pattern have been examined in such a manner.

Lipid histochemistry. Histochemical techniques for lipids have been used to study the ovaries of Myotis griesescens and Antrozous pallidus (Guraya \& Greenwald, 1964; Guraya, 1967, 1974; Oxberry, 1979). These studies show that the numerous, well developed interstitial cells derived from the theca interna of large atretic follicles function in the storage of lipid, cholesterol and/or steroid droplets during hibernation (P1. 2, Fig. 5), and that these droplets are mobilized during gestation, possibly in response to high levels of gonadotrophins produced by the pituitary or placenta or both.

Hydroxysteroid dehydrogenase histochemistry. The cellular location and relative activity of two enzymes, $3 \beta$-hydroxysteroid dehydrogenase (3 $\beta$-HSD) and $17 \beta$-hydroxysteroid dehydrogenase (17 $\beta$-HSD), both of which participate in the synthesis of oestrogen and/or progesterone, have been evaluated in the ovaries of Antrozous pallidus throughout the reproductive cycle (Oxberry, 1977, 1979). At the beginning of oestrus, 3 $\beta$-HSD becomes conspicuous in the numerous interstitial cells and theca interna of large follicles (Pl. 2, Fig. 6) and persists throughout hibernation. After ovulation, $3 \beta$-HSD reaches its greatest intensity in interstitial cells and in the corpus luteum of pregnancy (P1. 2, Fig. 7). After parturition, the corpus luteum involutes, and $3 \beta$-HSD cannot be detected until the onset of the next oestrus. Since LH is known to stimulate $3 \beta$-HSD activity, some of this gonadotrophin is probably present at the onset of oestrus; it is likely that the increase in $3 \beta$-HSD activity with the start of pregnancy can be attri- 
buted to augmented LH levels and/or placental chorionic gonadotrophin. At the beginning of oestrus, $17 \beta$-HSD is also detected in interstitial cells and the theca interna of large follicles; it persists throughout hibernation (PI. 2, Fig. 8). During pregnancy, however, 17 $\beta$-HSD is found only in interstitial cells, and after parturition it is not observed until the onset of the next oestrus. The activity of $17 \beta-H S D$ is specifically associated with the production of oestrogen and testosterone, while $3 \beta$-HSD activity can be related to the synthesis of several other sex steroids.

Radioimmunoassay. The circulating levels of oestrogen and progesterone in blood have been measured in Antrozous pallidus (Oxberry, 1979). The concentration of oestrogen rises with the onset of oestrus, but then falls to low levels during hibernation (Text-fig. 2). Upon spring arousal, the level appears to rise dramatically and then fall immediately after ovulation. As pregnancy proceeds, the oestrogen concentration increases, to reach a peak at mid-gestation. The levels then steadily fall to a low value immediately following parturition. Finally, a transient increase in oestrogen occurs during lactation. Progesterone remains at baseline levels from the onset of oestrus throughout hibernation (Text-fig. 3). Upon spring arousal, the levels increase significantly, particularly with the initial establishment of the corpus luteum after ovulation. At

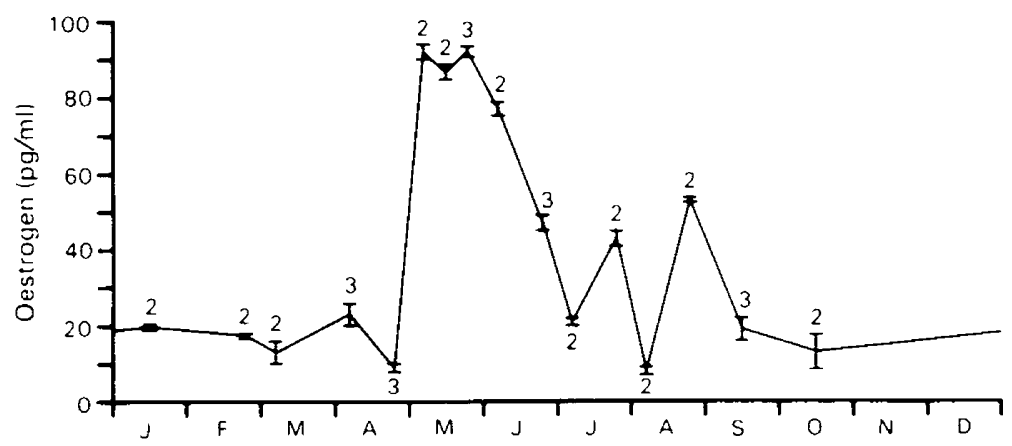

Text-fig. 2. Annual circulating levels of oestrogen in female Antrozous pallidus. Vertical bars represent the s.e.m. and the number of sample replicates at each point is indicated. Each sample consisted of pooled plasma and from $4-6$ bats.

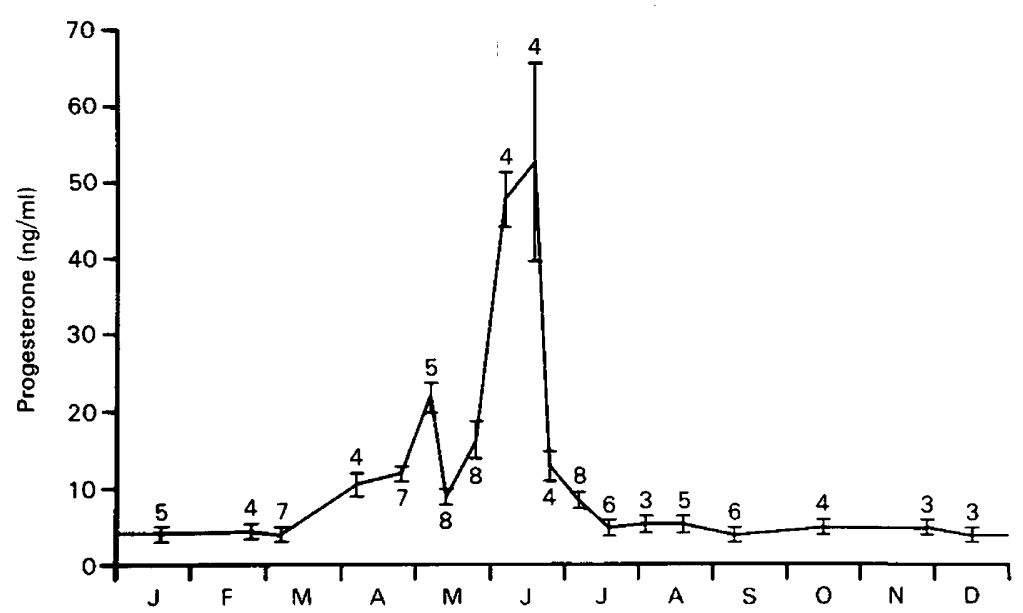

Text-fig. 3. Annual circulating levels of progesterone in female Antrozous pallidus. Vertical bars represent the s.e.m., numbers indicating the sample size. Each sample consisted of plasma from individual bats. 
the end of the first third of pregnancy, progesterone values fall significantly and then increase dramatically to reach a peak just before parturition before declining rapidly to baseline levels, where they remain until the beginning of the next oestrous cycle.

The levels of circulating sex steroids seem to correlate quite well with the evaluation of steroidogenic activity in the ovary. With respect to gonadotrophin control, the information on ovarian steroidogenesis in these bats indicates that $\mathrm{LH}$ is probably present at the onset of oestrus but does not normally reach ovulatory levels before the end of hibernation.

\section{Conclusions}

As far as they are known, the time relationships between reproductive events are altered in all hibernating bats. These modifications seem to include either a delay between copulation and ovulation or between fertilization and implantation. A possible third kind of delay, slowed or prolonged gestation after implantation has also been demonstrated experimentally (Racey, 1969, 1973b). The mean length of gestation can be extended by the induction of torpor at different stages during the pregnancy of bats kept in the laboratory. This modifiability supports the feeling of many observers that in the natural environment gestation in heterothermic bats (those capable of torpor) can be extended in response to adverse conditions. The common denominator in each of these delays is that the period of delay coincides with the period of torpor or hibernation.

The influence of torpor is certainly profound. While, superficially, torpor depresses metabolism, the reaction of the endocrine system to this state and probably to other internal, as well as environmental, stimuli are certainly the complex roots of the problem. Elucidation of the controlling endocrine mechanisms will require more intensive study of the structure and function of the ovary, pituitary and higher centres of control. Future efforts should probably be directed toward studies of the synthesis, secretion and receptor sites for pituitary and steroid hormones, with a more intensive application of high-resolution laboratory methods such as radioimmunoassay and immunocytochemistry. In addition, reproductive specializations, such as sperm storage, certainly deserve more in-depth study.

I should like to acknowledge the support of the Department of Anatomy, University of Arizona, and particularly that of Dr J. Angevine, who critically reviewed the manuscript, and that of Ms K. Cvitkovich, Ms T. Foster and Ms L. Bucherer who typed the manuscript.

\section{References}

Appley, M.D. (1971) Ultrastructural aspects of follicular growth and atresia in the ovary of the bat, Myotis grisescens. Ph.D. dissertation, University of Oklahoma.

Asdell, S.A. (1964) Patterns of Mammalian Reproduction. Cornell University Press, Ithaca, New York.

Brosset, A. (1961) L'hibernation chez les chiroptères tropicaux. Mammalia 25, 413-425.

Caffier, P. (1934) Hormonale Schwangerschaftserzeugung bei der winterschlafenden Fledermaus. Zentbl. Gynäk. 58, 2354-2363.

Caffier, P. \& Kolbow, H. (1934) Anatomischphysiologische Genitalstudien an Fledermäusen zur Klarung der therapeutischen Sexualhormonwirkung. Z. Geburtsh. Gynäk. 108, 185-235.

Carter, D.C. (1970) Chiropteran reproduction. In $A l l$ About Bats, pp. 233-246. Eds B. H. Slaughter \& D. W. Walton. Southern Methodist University Press, Dallas.
Christian, J.J. (1956) The natural history of a summer aggregation of the big brown bat, Eptesicus fuscus fuscus. Am. Midl. Nat. 55, 66-95.

Courrier, R. (1924) Le cycle sexuel chez la femelle des mammifères. Étude de la phase folliculaire. Archs Biol. 34, 369-477.

Courrier, R. (1927) Etude sur le déterminisme des caractères sexuels secondaires chez quelques mamifères a activité testiculaire périodique. Archs Biol. 37, 173-334.

Druecker, J.D. (1972) Aspects of reproduction in Myotis volans, Lasionycteris noctivagans, and Lasiurus cinereus. Ph.D. dissertation, University of New Mexico.

Dwyer, P.D. (1963) The breeding biology of Miniopterus schreibersii blepotis (Temminck) (Chiroptera) in northeastern New South Wales. Aust. J. Zool. 11, 219-240. 
Dywer, P.D. (1966) Observations on the eastern horseshoe bat in northeastern New South Wales. Helicitite 4, 73-82.

Dwyer, P.D. (1968) The biology, origin and adaptation of Miniopterus australis (Chiroptera) in New South Wales. Aust. J. Zool. 16, 49-68.

Eisentraut, M. (1936) Zur Fortpflanzungsbiologic der Fledermäuse. Z. Morph. Ökol. Tiere 31, 27-63.

Folk, G.E. (1940) The longevity of sperm in the female bat. Anat. Rec. 76, 103-109.

Guraya, S.S. (1967) Cytochemical study of interstitial cells in the bat ovary. Nature, Lond. 214, 614-616.

Guraya, S.S. (1974) Comparative morphological and histochemical observations on the ovarian stromal compartment in mammals with special reference to steroidogenesis. Acta anat. 90, 250-284.

Guraya, S.S. \& Greenwald, G.S. (1964) A comparative histochemical study of interstitial tissue and follicular atresia in the mammalian ovary. Anat. Rec. 149, 411-433.

Guthrie, M.J. (1933) The reproductive cycles of some cave bats. J. Mammal. 14, 199-216.

Guthrie, M.J. (1939) Reproductive cycles in animals with special reference to the bat. Growth 3, 261-275.

Guthrie, M.J. \& Jeffers, K.R. (1938a) A cytological study of the ovaries of the bats Myotis lucifugus lucifugus and Myotis grisescens. J. Morph. 62, 523557.

Guthrie, M.J. \& Jeffers, K.R. (1938b) Growth of follicles in the ovaries of the bat Myotis lucifugus lucifugus. Anat. Rec. 71, 477-496.

Guthrie, M.J. \& Jeffers, K.R. (1938c) The ovaries of the bat Myotis lucifugus lucifugus after injection of hypophyseal extracts. Anat. Rec. 72, 11-36.

Guthrie, M.J. \& Smith, E.W. (1940) The pregnancy urine factor as a stimulus for ovulation in the bat and augmentation of its effect. Anat. Rec. 76, 66.

Guthrie, M.J., Jeffers, K.R. \& Smith, E.W. (1951) Growth of follicles in the ovaries of the bat Myotis grisescens. J. Morph. 88, 127-144.

Hartman, C.G. (1933) On the survival of spermatozoa in the female genital tract of the bat. Q. Rev. Biol. 8, $185-193$.

Henshaw, R.E. (1970) Thermoregulation in bats. In All about Bats, pp. 188-232. Eds B. H. Slaughter \& D. W. Walton. Southern Methodist University Press, Dallas.

Herlant, M. (1954) Influence des oestrogènes chez le Murin (Myotis myotis) hibernant. Bull. Acad. r. Belg. Cl. Sci. 40, 408-415.

Herlant, M. (1965) Corrélations hypophyso-génitales chez la femelle de la chauve-souris, Myotis myotis (Borkhausen). Archs Biol. 67, 89-180.

Herlant, M. (1968) Cycle sexual chez les chiroptères des regions tempérées. In Cycles Génitaux Saissoniers des Mamifères Sauvages, pp. 111-126. Ed. R. Canivenc. Masson, Paris.

Kitchener, D.J. (1975) Reproduction in female Gould's wattled bat, Chalinolobus gouldii (Gray) (Vespertiliondae), in western Australia. A ust. J. Zool. 23, 2942.

Kleiman, D.G. (1969) Maternal care, growth rate, and development in the noctule (Nyctalus noctula), pipistrelle (Pipistrellus pipistrellus), and serotine (Eptesicus serotinus) bats. J. Zool., Lond. 157, $187-211$.
Krutzsch, P.H. (1975) Reproduction of the canyon bat, Pipistrellus hesperus, in southwestern United States. Am. J. Anat. 143, 163-200.

Kulzer, E. (1965) Temperaturregulation bei Fledermäusen (Chiroptera) aus verschiedenen Klimazonen. J. comp. Physiol. 50, 1-34.

Lyman, C.P. (1970) Thermoregulation and metabolism in bats. In Biology of Bats, Vol. 1, pp. 301-330. Ed. W. A. Wimsatt. Academic Press, New York.

Matthews, L.H. (1937) The female sexual cycle in British horse-shoe bats, Rhinolophus ferrum-equinum insulanus Barrett-Hamilton and $R$. hipposideros minutus Montagu. Trans. Zool. Soc. Lond. 23, 224 266.

McNab, B.K. (1969) The economics of temperature regulation in neotropical bats. Comp. Biochem. Physiol. 31, 227-268.

Nakano, O. (1928) Über die Verteilung des Glykogens bei den zyklischen Veränderungen in den Geschlechtsorganen der Fledermaus, und über die Nahrungsaufnahme der Spermien in den weiblichen Geschlechtswege. Folia anat. jap. 6, 777-828.

Orr, R.T. (1954) Natural history of the pallid bat, Antrozous pallidus (Le Conte). Proc. California Acad. Sci. 28, 165-246.

Oxberry, B.A. (1977) Ovarian morphology and steroidogenesis in the pallid bat, Antrozous pallidus. Anat. Rec. 187, 673, Abstr.

Oxberry, B.A. (1979) The reproductive biology of the female vespertilionid bat, Antrozous pallidus. Ph.D. dissertation, University of Arizona.

Pearson, O.P., Koford, M.R. \& Pearson, A.K. (1952) Reproduction of the lump-nosed bat (Corynorhinus rafinesquei) in California. J. Mammal. 33, 273-320.

Peyre, A. \& Herlant, M. (1963a) Ovo-implantation différée et corrélations hypophyso-génitales chez la femelle du Minioptère (Miniopterus schreibersii B.). C.r. hebd. Séanc. Acad. Sci., Paris D 257, 524-526.

Peyre, A. \& Herlant, M. (1963b) Correlations hypophyso-genitales chez la femelle du Minioptère (Miniopterus schreibersii B.). Gen comp. Endocr. 3, $726-727$.

Peyre, A. \& Herlant, M. (1967) Ovo-implantation différée et déterminisme hormonal chez le Minioptère, Miniopterus schreibersii K. (Chiroptère). C.r. Séanc. Soc. Biol. 161, 1779-1782.

Planel, H.G., Guilhem, A. \& Soleilhavoup, J.P. (1961) Le cycle annuel du cortex surrénal d'un semihibernant Miniopterus schreibersii. C.r. Ass. Anat. 47, 620-633.

Racey, P.A. (1969) Diagnosis of pregnancy and experimental extension of gestation in the pipistrelle bat, Pipistrellus pipistrellus. J. Reprod. Fert. 19, 465-474.

Racey, P.A. (1973a) The viability of spermatozoa after prolonged storage by male and female bats. Period. Biol. 75, 201-205.

Racey, P.A. (1973b) Environmental factors affecting the length of gestation in heterothermic bats. J. Reprod. Fert., Suppl. 19, 175-187.

Racey, P.A. (1976) Induction of ovulation in the pipistrelle bat, Pipistrellus pipistrellus. J. Reprod. Fert. 46, 481-483.

Downloaded from Bioscientifica.com at 04/26/2023 02:10:34PM via free access 
Racey, P.A. (1979) The prolonged storage and survival of spermatozoa in Chiroptera. J. Reprod. Fert. 56, $391-402$.

Ramakrishna, P.A. \& Rao, K.V.B. (1977) Reproductive adaptations in the Indian rhinolophid bat, Rhinolophus rouxi (Temminck), Curr. Sci. 46, 270271.

Reeder, E.M. (1939) Cytology of the reproductive tract of the female bat Myotis lucifugus lucifugus. $J$. Morph. 64, 431-453.

Richardson, E.G. (1976) The biology and evolution of the reproductive cycle of Miniopterus schreibersii and M. australis (Chiroptera: Vespertilionidae) in eastern Australia. Ph.D. dissertation, University of Queensland.

Richardson, E.G. (1977) The biology and evolution of the reproductive cycle of Miniopterus schreibersii and $M$. australis (Chiroptera: Vespertilionidae). $J$. Zool., Lond. 183, 353-375.

Skreb, N. (1955) Influence des gonadotrophines sur les noctules (Nyctalus noctula) en hibernation. C.r. Séanc. Soc. Biol. 149, 71-74.

Sluiter, J.W. \& Bels, L. (1951) Follicular growth and spontaneous ovulation in captive bats during the hibernation period. Proc. K. ned. Akad. Wet. Sec. C 54, 585-593.

Sluiter, J.W. \& Bowman, M. (1951) Sexual maturity in bats of the genus Myotis. I. Size and histology of the reproductive organs during hibernation in connection with age and wear of the teeth in female Myotis myotis and Myotis emarginatus. Proc. K. ned. Akad. Wet. Sec. C 54, 594-602.

Sluiter, J.W., Bels, L. \& Van Oordt, G.J. (1952) The reproductive organs of female bats (Myotis myotis) following administration of large doses of gonadotrophins during the hibernation period. Acta endocr., Copenh. 9, 258-270.

Smith, E.W. (1951) Seasonal response of follicles in the ovaries of the bat Myotis grisescens to pregnancy urine gonadotrophin. Endocrinology 49, 67-72.
Studier, E.H. \& O'Farrell, M.J. (1972) Biology of Myotis thysanodes and $M$. lucifugus (Chiroptera: Vespertilionidae). I. Thermoregulation. Comp. Biochem. Physiol. 41A, 567-595.

Wimsatt, W.A. (1942) Survival of spermatozoa in the female reproductive tract of the bat. Anat. Rec. 83, 299-307.

Wimsatt, W.A. (1944a) Growth of the ovarian follicle and ovulation in Myotis lucifugus lucifugus. Am. J. Anat. 74, 129-173.

Wimsatt, W.A. (1944b) Further studies on the survival of spermatozoa in the female reproductive tract of the bat. A nat. Rec. 88, 193-204.

Wimsatt, W.A. (1945) Notes on breeding behavior, pregnancy, and parturition in some vespertilionid bats of the eastern United States. J. Mammal. 26, 23-33.

Wimsatt, W.A. (1960) Some problems of reproduction in relation to hibernation in bats. Bull. Mus. comp. Zool. Harv. 124, 249-270.

Wimsatt, W.A. (1969) Some interrelations of reproduction and hibernation in mammals. Symp. Soc. exp. Biol. 23, 511-549.

Wimsatt, W.A. (1975) Some comparative aspects of implantation. Biol. Reprod. 12, 1-40.

Wimsatt, W.A. \& Kallen, F.C. (1957) The unique maturation response of the Graafian follicles of hibernating vespertilionid bats and the question of its significance. Anat. Rec. 129. 115-132.

Wimsatt, W.A. \& Parks, H.F. (1966) Ultrastructure of the surviving follicle of hibernation and of the ovumfollicle cell relationship in the vespertilionid bat Myotis lucifugus. Symp. Zool. Soc., Lond. 15, 419 454.

Zondek, B. (1933) Action of folliculin and prolan on the reproductive organs of the bat during hibernation. Lancet ii, $1256-1257$. 